\title{
trajectory of bacterial communities in soil are shaped by plant-driven changes during secondary succession
}

\section{Mayank Krishna, Shruti Gupta, Manuel Delgado - Baquerizo, Elly Morriën, Satish Chandra Garkoti, Rupesh Chaturvedi \& Shandar Ahmad}

Correction to: Scientific Reports https://doi.org/10.1038/s41598-020-66638-x, published online 17 June 2020

This Article contains a typographical error the Author Contributions section.

"M.K., S.C.G., R.C. designed research, M.K. performed research, M.K., S.C.G., S.A., M.D., E.M. analysed data, S.C.G., R.C. contributed new reagents and analytical tools, M.K. wrote the paper with inputs from all authors."

should read:

"M.K, S.C.G, R.C designed research, M.K. performed research, M.K, S.G, M.D, E.M, S.A analysed and interpreted the data, R.C, S.C.G contributed new reagents, M.K wrote the paper with inputs from all authors."

\begin{abstract}
Open Access This article is licensed under a Creative Commons Attribution 4.0 International License, which permits use, sharing, adaptation, distribution and reproduction in any medium or format, as long as you give appropriate credit to the original author(s) and the source, provide a link to the Creative Commons license, and indicate if changes were made. The images or other third party material in this article are included in the article's Creative Commons license, unless indicated otherwise in a credit line to the material. If material is not included in the article's Creative Commons license and your intended use is not permitted by statutory regulation or exceeds the permitted use, you will need to obtain permission directly from the copyright holder. To view a copy of this license, visit http://creativecommons.org/licenses/by/4.0/.
\end{abstract}

(C) The Author(s) 2020 